\title{
Flaviramulus basaltis gen. nov., sp. nov., a novel member of the family Flavobacteriaceae isolated from seafloor basalt
}

Correspondence

Jørn Einen

jorn.einen@bio.uib.no

\author{
Jørn Einen and Lise Øvreås \\ Department of Biology, University of Bergen, Jahnebakken 5, 5020 Bergen, Norway
}

According to Garrity et al. (2005), the family Flavobacteriaceae (Reichenbach, 1989; Bernardet et al., 1996, 2002) is placed within the class Flavobacteria, one of three classes in the phylum Bacteroidetes. Novel members of the family Flavobacteriaceae have been described frequently in recent years. Of the 53 genera within the family at the time of writing, 27 were proposed in 2004 or later. Some genera contain species found in soil, freshwater and in association with humans and animals as commensals or as opportunistic pathogens. However, 37 of the genera within the Flavobacteriaceae, nearly all proposed since 1997, include species isolated from marine systems. Members of the marine clade (Bowman, 2005) of the family Flavobacteriaceae are thought to play an important role in the degradation of complex biological macromolecules in the marine environment (Kirchman, 2002).

Samples of basaltic pillow lavas were collected from the sea floor during the SUBMAR 2001 cruise to the Jan Mayen platform in the Norwegian/Greenland Sea $\left(71^{\circ} 04^{\prime} 38^{\prime \prime} \mathrm{N} 7^{\circ}\right.$ $\left.29^{\prime} 6^{\prime \prime} \mathrm{W}\right)$. The samples were collected by dredging at a depth of $1300 \mathrm{~m}$. The sea floor temperature at the sampling site

The GenBank/EMBL/DDBJ accession number for the 16S rRNA gene sequence of Flaviramulus basaltis $\mathrm{H}_{3} 5^{\top}$ is DQ361033. was $-0 \cdot 7^{\circ} \mathrm{C}$. Immediately after the samples were on deck, the outer glassy rim of the pillow basalt was chipped off. The glass was added to sterile seawater and stored in closed $100 \mathrm{ml}$ flasks in darkness for 3 years at $10^{\circ} \mathrm{C}$. Subsamples were plated onto marine broth 2216 (Difco; MB) with $1.5 \%$ agar, and incubated at $10^{\circ} \mathrm{C}$. After 14 days incubation, four yellow colonies were picked. Strains from these four colonies (designated $\mathrm{H} 32, \mathrm{H} 33, \mathrm{H} 34$ and $\mathrm{H} 35^{\mathrm{T}}$ ) were purified, and preserved in $\mathrm{MB}$ supplemented with $15 \%$ glycerol at $-80^{\circ} \mathrm{C}$.

Unless stated otherwise the strains were grown in Flavobacteriaceae medium (FM; $30 \mathrm{~g}$ Sigma sea salts $1^{-1}$, $5 \mathrm{~g}$ D-glucose $1^{-1}, 0.5 \mathrm{~g}$ yeast extract $1^{-1}$, adjusted to $\mathrm{pH} 8 \cdot 0$ ) at a temperature of $22^{\circ} \mathrm{C}$. Gram staining, oxidase, catalase and alkaline phosphatase tests were performed as described by Smibert \& Krieg (1994). The ability of the strains to hydrolyse agar, gelatin, chitin, cellulose (CF11 powder; Whatman), starch, urea, aesculin and DNA was examined according to the procedures of Smibert \& Krieg (1994). Hydrolysis of L-tyrosine was examined as described by Collins (1995). Hydrolysis of Tweens was examined as described by Slifkin (2000). The hydrolysis tests were performed on $\mathrm{MB}+1.5 \%$ agar (MA) medium at an incubation temperature of $15^{\circ} \mathrm{C}$. FM supplemented with 
cysteine. $\mathrm{HCl}$ to a final concentration of $0.05 \%$ was used to examine the ability of the strains to produce $\mathrm{H}_{2} \mathrm{~S}$ from cysteine (Smibert \& Krieg, 1994). FM without glucose and with $0 \cdot 15 \%$ phenol red was used to test for the production of acids from a variety of sugars supplemented to a final concentration of $1 \%$. FM with appropriate modifications was used to examine the requirement for growth factors.

Temperature, $\mathrm{pH}$ and salinity range and optimum were examined by measuring growth in 96 -well microtitre plates. Growth was measured as $\mathrm{OD}_{630}$. To determine the temperature range for growth, the strains were grown in $\mathrm{MB}$. For $\mathrm{pH}$ determination, the strains were grown in FM supplemented with $50 \mathrm{mM}$ buffer. The following buffer systems ( $\mathrm{pH}$ range) were used: citric acid $(3 \cdot 5-4 \cdot 0)$, acetic acid $(4 \cdot 5-5 \cdot 5)$, PIPES $(6 \cdot 0-7 \cdot 4)$, HEPES $(7 \cdot 6-8 \cdot 0)$ and Tris $(8 \cdot 2-10 \cdot 5)$. For the salinity experiments, FM with different sea salt concentrations was used. The strains were tested for fermentative growth on MB and FM. To test for anaerobic respiration, $\mathrm{MB}$ and FM supplemented with $\mathrm{NaNO}_{3}, \mathrm{Fe}$ (III) citrate or amorphous $\mathrm{Mn}(\mathrm{IV})$ oxide to $0 \cdot 2 \%$ were used. The anaerobic medium was flushed with $\mathrm{N}_{2}$ immediately after autoclaving to remove $\mathrm{O}_{2}$. The medium was then supplemented with $\mathrm{NaHCO}_{3}$ to a final concentration of $0.5 \%(\mathrm{w} / \mathrm{v})$ to help facilitate anaerobic growth (Reichenbach, 1989).

Substrate use was examined using Biolog GN2 plates as described by the manufacturer except that the plates were inoculated with cells grown on MA, and suspended in $1.5 \%$ Sigma sea salts to an $\mathrm{OD}_{590}$ of $\sim 0 \cdot 3$. The plates were incubated at $15{ }^{\circ} \mathrm{C}$ and manually read after 14 days incubation. The ability of the strains to use methanol, ethanol, 2-propanol or glycerol as sole carbon and energy sources was tested using FM as described, but without Dglucose, as the base medium. The medium was then supplemented with the appropriate alcohol to a final concentration of $1 \%$.

DNA was isolated using the method described by Marmur (1963). DNA G + C content was determined by the thermal denaturation method (Mandel et al., 1970). Fatty acid methyl ester and quinone analyses were carried out by the Identification Service of the DSMZ (Braunschweig, Germany).

$16 \mathrm{~S}$ rRNA genes from the four strains were PCR amplified, sequenced and assembled to a 1422-bp-long fragment by using standard methods. Percentage sequence similarity between the basalt strains and the type species of genera in the the family Flavobacteriaceae was determined by the global alignment program MATGAT (Campanella et al., 2003). Closely related sequences were selected for generation of phylogenetic trees using the neighbour-joining, maximum-likelihood and maximum-parsimony algorithms. The neighbour-joining tree was constructed in CLUSTAL_X (Thompson et al., 1997) and bootstrap values were calculated based on 1000 replications. Maximum-likelihood and maximum-parsimony trees were constructed in PHYLIP (Felsenstein, 2004).
Pigments were extracted from cells grown without light in MB using ethanol. The cellular residues were removed by centrifugation. An adsorption spectrum (175-900 nm) was obtained from the crude cell extract using a Cary 4E UVvisible spectrophotometer (Varian). Cell pigments were also extracted using acetone, and separated by TLC using cellulose-covered plastic plates (Merck) and petroleum ether/acetone $(9: 1)$ as the chromatographic liquid. The separated pigments were cut out and extracted in acetone. An adsorption spectrum $(390-700 \mathrm{~nm})$ was obtained from the separated pigments using a UV mini 1240 spectrophotometer (Shimadzu). Cellulophaga lytica DSM $7489^{\mathrm{T}}$ was used as a reference in the pigment analysis (Lewin \& Lounsbery, 1969). To detect flexirubin-type pigments, the bathochromic shift test with $20 \%(\mathrm{w} / \mathrm{v}) \mathrm{KOH}$ (Reichenbach, 1989) was performed.

Phenotypic and genotypic analysis could not differentiate the four strains $\mathrm{H} 32, \mathrm{H} 33, \mathrm{H} 34$ and $\mathrm{H} 35^{\mathrm{T}}$. The $16 \mathrm{~S}$ rRNA gene sequences from the four strains were also identical.

Cells in exponential growth phase were rod-shaped, with a diameter of $0 \cdot 2-0 \cdot 3 \mu \mathrm{m}$ and a length of $1-3 \mu \mathrm{m}$. Cells in stationary phase were pleomorphic with a diameter of $0 \cdot 2-0.3 \mu \mathrm{m}$ and lengths ranging from 1 to $30 \mu \mathrm{m}$. In stationary-phase cultures, branched and curled cells were also observed (Fig. 1). As cultures aged, cells degenerated into spheroplasts ranging from $0 \cdot 15$ to $0 \cdot 5 \mu \mathrm{m}$ in diameter (Fig. 1). After 1 month incubation under optimum conditions, nearly all cells had degenerated into spheroplasts, which were found to be non-viable. The strains must, however, be able to survive for at least 3 years at $10{ }^{\circ} \mathrm{C}$ on seawater and basalt given that they could be cultivated from the inoculum. Cells displayed gliding motility. Motility was best observed in fresh cultures grown in FM with $<0.05 \%$

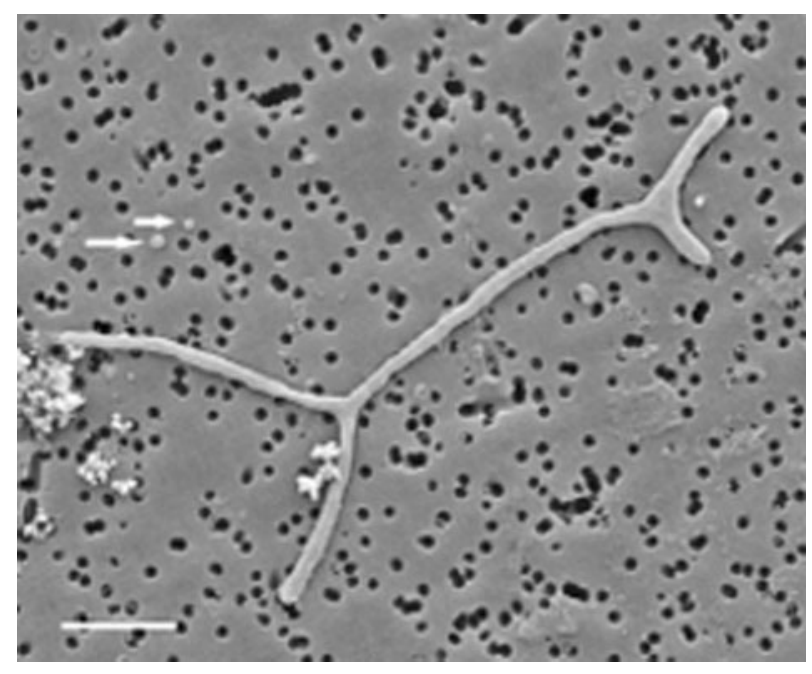

Fig. 1. Scanning electron micrograph of cells of strain $\mathrm{H} 35^{\top}$ from a 2-week-old culture, grown in $\mathrm{MB}$ and incubated at $4{ }^{\circ} \mathrm{C}$. Arrows indicate spheroplasts. Bar, $2 \mu \mathrm{m}$. 
yeast extract. No spreading growth was observed on MA or FM plates. Cells were observed by microscopy to be motile by polar adhesion to the glass slide, with a rotational movement of about 3 rotations $\mathrm{s}^{-1}$. Cells gripped the surface at the opposite pole and then released at the first pole. This behaviour has been described previously for members of the family Flavobacteriaceae (Lapidus \& Berg, 1982). Polar appendage structures (Fig. 2) were observed by scanning electron microscopy on many of the cells that were motile. These structures were not observed on non-motile cells.

The basaltic strains were obligately aerobic and heterotrophic. They had a temperature range from -2 to $34^{\circ} \mathrm{C}$ with an optimum growth rate at $18-23^{\circ} \mathrm{C}$. The strains had a pH range from $6 \cdot 5$ to $8 \cdot 6$, with an optimum growth rate at $\mathrm{pH} 6 \cdot 5-8 \cdot 2$. The strains grew at $3-60$ g sea salts $1^{-1}$, with an optimum growth rate at $24-60 \mathrm{~g} \mathrm{l}^{-1}$. The strains required seawater or artificial seawater for growth. The strains also had requirements for thiamine and unknown amino acid(s), but grew well in media supplemented with yeast extract to a final concentration of $0.05 \%(\mathrm{w} / \mathrm{v})$. The strains were able to utilize and produce acids from $(+)$-L-rhamnose, $(-)$-Dfructose, maltose, sucrose, $(+)$-D-glucose, $(-)$-D-arabinose, (+)-D-cellobiose, (-)-D-ribose, xylan, lactose and $(-)$-D-mannitol. None of the tested alcohols supported growth. The strains were able to use the following substrates in the Biolog system: cyclodextrin, D-glucose, D-glucose 1phosphate, D-lactose, ketobutyric acid, ketoglutaric acid, methyl D-glucoside, DL-lactic acid, D-cellobiose, dextrin, Dfructose, D-galactose, D-galacturonic acid, D-glucose 6phosphate, D-glucuronic acid, D-mannose, D-raffinose, D-trehalose, gentiobiose, glycogen, glycyl L-aspartic acid,

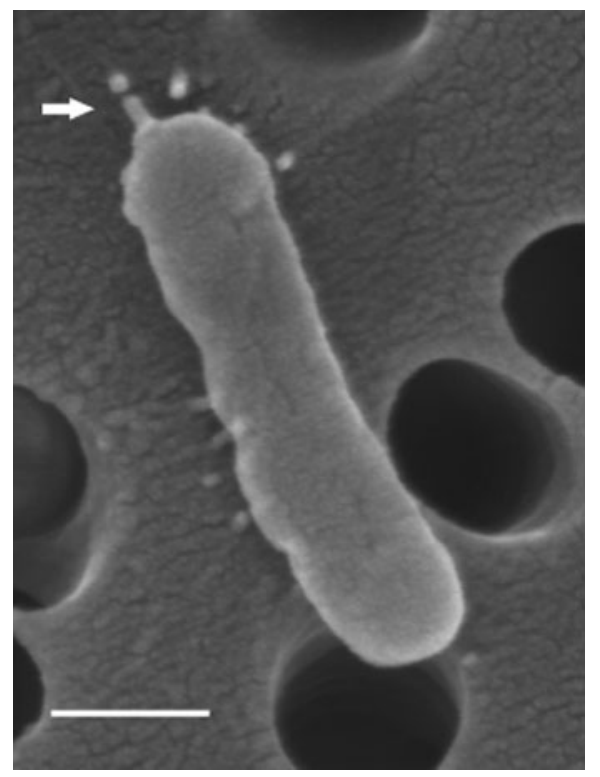

Fig. 2. Scanning electron micrograph of a cell of strain $\mathrm{H} 35^{\top}$ grown on $\mathrm{FM}$ at $22^{\circ} \mathrm{C}$, showing a polar appendage structure (arrow). Bar, $0.2 \mu \mathrm{m}$. glycyl L-glutamic acid, lactulose, L-aspartic acid, L-glutamic acid, L-ornithine, L-proline, L-rhamnose, maltose, $\mathrm{N}$-acetylD-glucosamine, pyruvic acid methyl ester, succinamic acid, succinic acid, succinic acid monomethyl ester, sucrose, turanose, and Tweens 40 and 80. The following Biolog substrates were not utilized: $\alpha$-, $\beta$ - and $\gamma$-hydroxybutyric acid, ketovaleric acid, acetic acid, adonitol, bromosuccinic acid, cis-aconitic acid, citric acid, D-alanine, D-arabitol, Dgalactonic acid lactone, D-gluconic acid, D-glucosaminic acid, D-mannitol, D-melibiose, D-psicose, D-saccharic acid, D-sorbitol, formic acid, glucuronamide, hydroxy-L-proline, i-erythritol, itaconic acid, L-alaninamide, L-alanine, L-alanyl glycine, L-arabinose, L-asparagine, L-fucose, L-histidine, Lleucine, L-phenylalanine, L-pyroglutamic acid, malonic acid, myo-inositol, $N$-acetyl-D-galactosamine, p-hydroxyphenylacetic acid, propionic acid, quinic acid, sebacic acid and xylitol. Further phenotypic characteristics are given in the species description.

Flexirubin-type pigments were not detected. Crude cell extracts from the strains had identical adsorption spectra to that of Cellulophaga lytica with peaks at 264, 334, 451 and $478 \mathrm{~nm}$ and a shoulder at $425 \mathrm{~nm}$. Two pigments with typical carotenoid-like spectra were separated by TLC of acetone extract. One orange pigment had adsorption peaks at 451,477 and $503 \mathrm{~nm}$, and one yellow pigment had adsorption peaks at 431 and $451 \mathrm{~nm}$ and a shoulder at $475 \mathrm{~nm}$. The chromatography profile and adsorption patterns of pigments from the basaltic strains were identical to those of C. lytica. C. lytica pigments are identified as zeaxanthin (Aasen \& Ljaaen, 1966; Lewin \& Lounsbery, 1969). The mean DNA G $+C$ content of the four new strains was $31 \cdot 4 \pm 0.6 \mathrm{~mol} \%$ (SD). The cellular fatty acid profile of strain $\mathrm{H} 35^{\mathrm{T}}$ is summarized in Table 1 . The predominant fatty acids were $15: 0$ iso, $15: 1$ iso, $15: 0$ iso $3-\mathrm{OH}$ and $17: 0$ iso $3-\mathrm{OH}$. The branched fatty acids accounted for $89 \%$ of all identified fatty acids. The quinone analysis showed that $99 \%$ of the quinones were menaquinone- 6 and $1 \%$ menaquinone-7.

The phylogenetic affiliation of the four new strains was examined by $16 \mathrm{~S}$ rRNA gene sequence analysis (Fig. 3). Strain $\mathrm{H} 35^{\mathrm{T}}$ formed a clade together with Gaetbulibacter saemankumensis and Algibacter lectus. Levels of 16S rRNA gene sequence similarity to the type strains of these two species were almost equal, $94 \cdot 3$ and $94 \cdot 8 \%$, respectively. $\mathrm{H} 35^{\mathrm{T}}$ also showed high $16 \mathrm{~S}$ rRNA gene sequence similarity to the type strains of members of the genera Formosa (Formosa algae, 93\%), Bizionia (Bizionia paragorgiae, 94.4\%), Lacinutrix (Lacinutrix copepodicola, 93.9\%) and Winogradskyella (Winogradskyella eximia, 93.6\%), which were placed in a clade separate from that containing $\mathrm{H} 35^{\mathrm{T}}$. The three algorithms used for construction of the phylogenetic trees generated the same branching in the Algibacter-Gaetbulibacter-Formosa-Bizionia clade to which strain $\mathrm{H} 35^{\mathrm{T}}$ is affiliated, but neighbour-joining bootstrapping values indicated that this tree had low bootstrapping values at some key branching points. 
Table 1. Fatty acid content of strain $\mathrm{H} 35^{\top}$ and the type species of some closely related reference genera

Taxa: 1, strain $\mathrm{H}_{35}{ }^{\mathrm{T}}$; 2, Algibacter lectus (data from Nedashkovskaya et al., 2004); 3, Gaetbulibacter saemankumensis (data from Jung et al., 2005); 4, Formosa algae (data from Ivanova et al., 2004); 5, Bizionia paragorgiae (data from Nedashkovskaya et al., 2005b); 6, Lacinutrix copepodicola (data from Bowman \& Nichols, 2005); 7, Winogradskyella eximia (data from Nedashkovskaya et al., 2005a). Fatty acids not found in strain $\mathrm{H}_{3} 5^{\mathrm{T}}$ and representing $<1 \%$ of total fatty acid content in the other species are not represented.

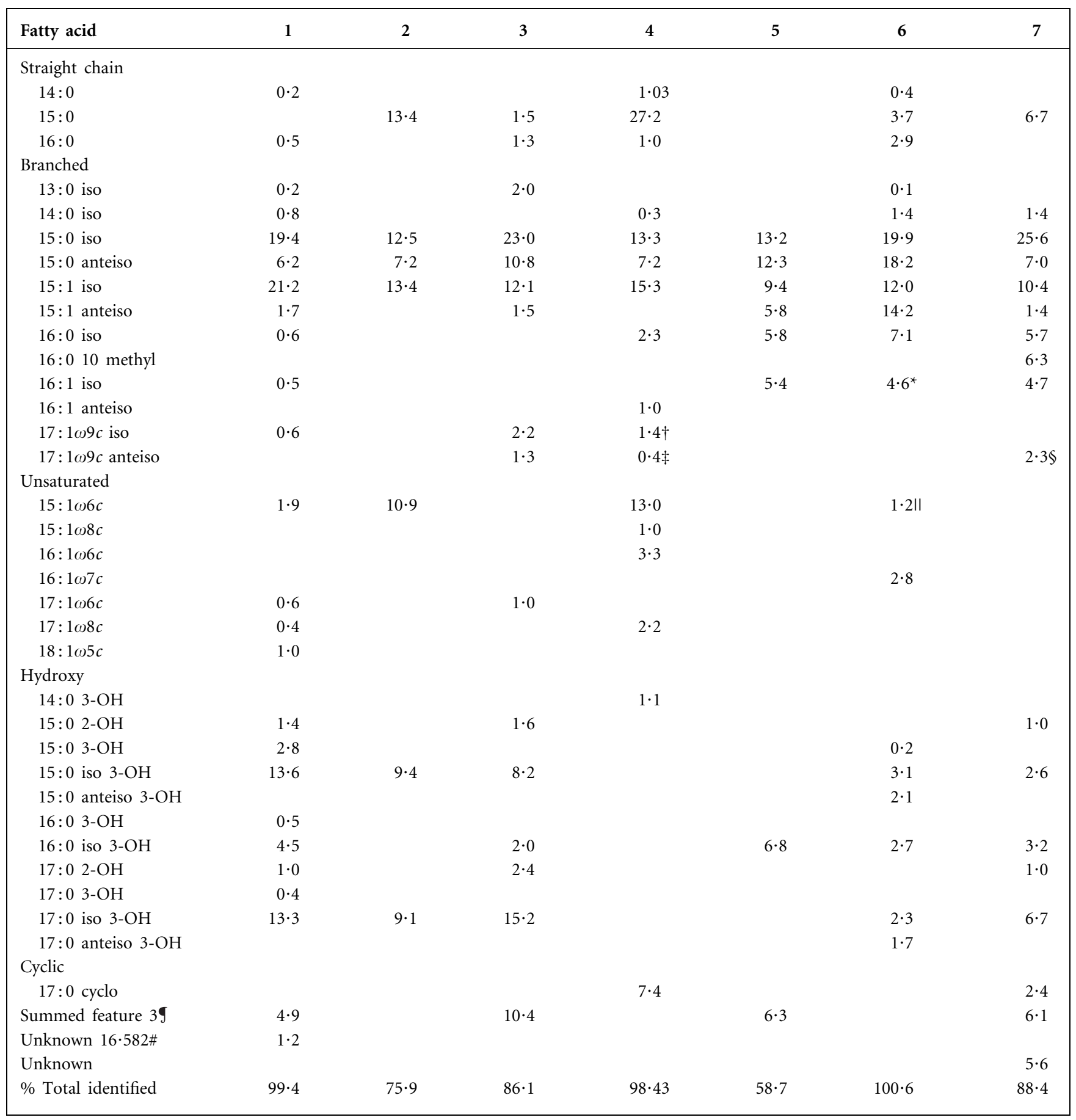

${ }^{*}$ Branching unknown, iso and/or anteiso.

$\dagger$ Reported by Ivanova et al. (2004) as $17: 1$ iso.

$\ddagger$ Reported by Ivanova et al. (2004) as $17: 1$ anteiso.

§Reported by Nedashkovskaya et al. (2005a) as 17:1 anteiso.

IIPosition of unsaturation unknown.

SSummed feature 3 represents the two fatty acids 15:0 iso $2-\mathrm{OH}$ and/or 16:1 $1 \omega 7 c$, which could not be separated.

\#Unknown $16 \cdot 582$ represents an unidentified fatty acid with an equivalent chain length of $16 \cdot 582$. 


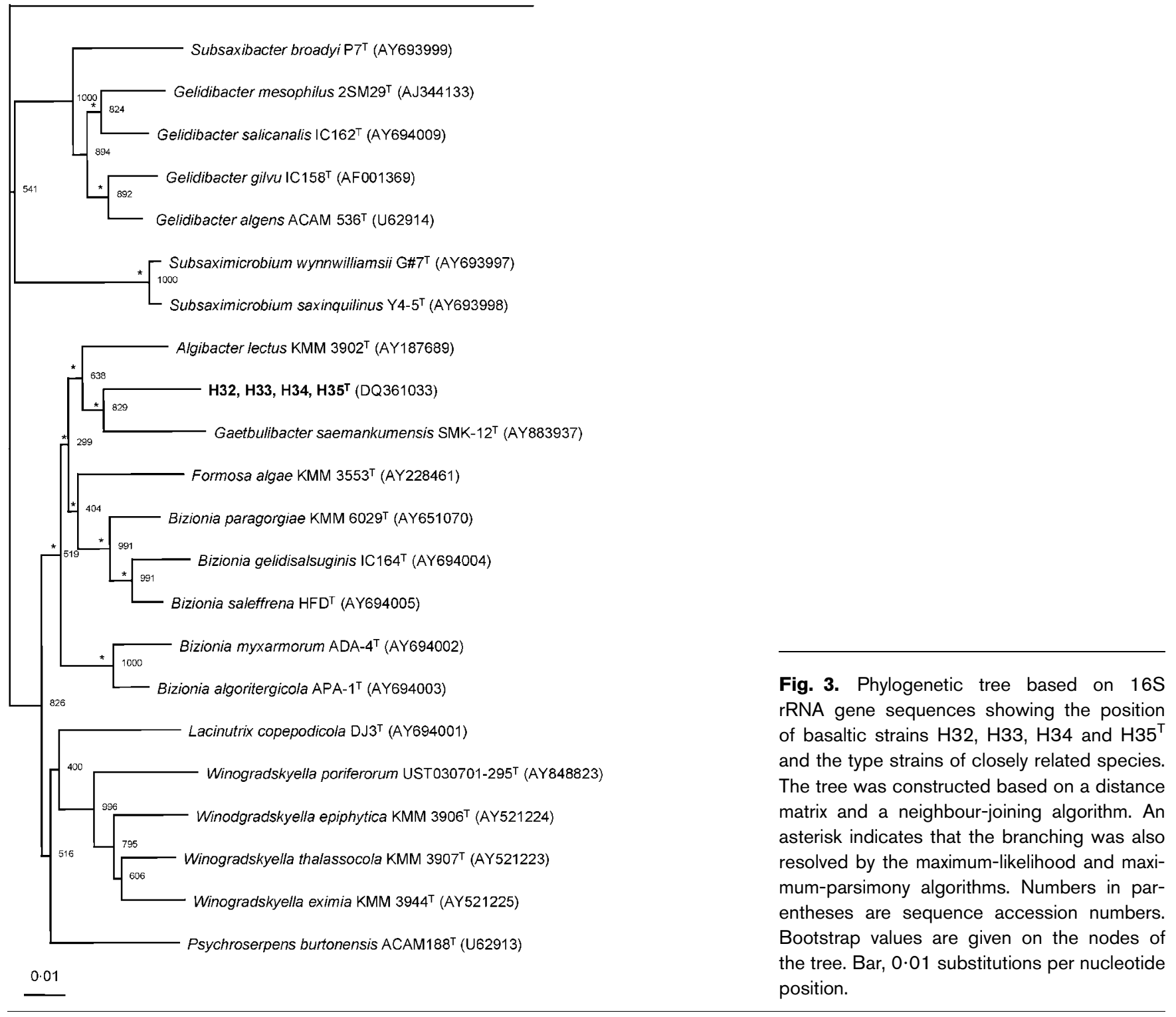

Fig. 3. Phylogenetic tree based on $16 \mathrm{~S}$ A gene sequences showing the position (a) strains $\mathrm{H} 32, \mathrm{H} 33, \mathrm{H} 34$ and $\mathrm{H}_{3}{ }^{\mathrm{T}}$ The tree was constructed based on a distance matrix and a neighbour-joining algorithm. An asterisk indicates that the branching was also resolved by the maximum-likelihood and maximum-parsimony algorithms. Numbers in parentheses are sequence accession numbers. odes of position.
Menaquinone- 6 was the major respiratory quinone in cells of strain $\mathrm{H} 35^{\mathrm{T}}$, constituting $99 \%$ of the total quinones. The basaltic strains also lacked the ability to hydrolyse cellulose. These two characteristics (Bernardet et al., 2002), together with results from $16 \mathrm{~S}$ rRNA gene sequence analysis, indicate that the strains belong within the family Flavobacteriaceae. Strain $\mathrm{H} 35^{\mathrm{T}}$ showed less than $97 \% 16 \mathrm{~S}$ rRNA gene sequence similarity to any recognized species and therefore it is likely to represent a novel species (Stackebrandt \& Goebel, 1994). Based on the phylogenetic analysis (Fig. 3), H35 ${ }^{\mathrm{T}}$ might be placed within one of two genera, Gaetbulibacter or Algibacter. The fatty acid profile of $\mathrm{H} 35^{\mathrm{T}}$ shows many similarities with that of Gaetbulibacter saemankumensis (Table 1). However, several of the phenotypic characteristics of the basaltic strains differ from those of members of the genera Gaetbulibacter and Algibacter (Table 2), the most important difference being that the basaltic strains are obligately aerobic, whereas Gaetbulibacter and Algibacter species are capable of fermentation/anaerobic respiration.

The basaltic strains also show high $16 \mathrm{~S}$ rRNA gene sequence similarity to members of the genera Bizionia, Lacinutrix and Winogradskyella. Phylogenetic analysis, however, does not support the placement of the strains in these genera (Fig. 3), which is corroborated by several phenotypic and chemotaxonomic characteristics (Table 2) such as motility, and temperature and salinity requirements.

Based on these results, we suggest that the four strains should be included in the family Flavobacteriaceae (Bernardet et al., 2002) as representatives of a novel species in a new genus, for which the name Flaviramulus basaltis gen. nov., sp. nov. is proposed. 
Table 2. Differential characteristics of strain $\mathrm{H}_{3} 5^{\top}$ and the type species of other phylogenetically related genera

Taxa: 1, strain $\mathrm{H}_{35} 5^{\mathrm{T}} ; 2$, Algibacter lectus (data from Nedashkovskaya et al., 2004); 3, Gaetbulibacter saemankumensis (data from Jung et al., 2005); 4, Formosa algae (data from Ivanova et al., 2004); 5, Bizionia paragorgiae (data from Nedashkovskaya et al., 2005b); 6, Lacinutrix copepodicola (data from Bowman \& Nichols, 2005); 7, Winogradskyella eximia (data from Nedashkovskaya et al., 2005a). +, Positive; -, negative; ND, not determined.

\begin{tabular}{|lccccccc|}
\hline Characteristic & $\mathbf{1}$ & $\mathbf{2}$ & $\mathbf{3}$ & $\mathbf{4}$ & $\mathbf{5}$ & $\mathbf{6}$ & $\mathbf{7}$ \\
\hline Oxidase & - & + & + & - & + & $\mathrm{ND}$ & + \\
Motility & + & + & + & + & - & - & + \\
Requirement for growth factors & + & $\mathrm{ND}$ & $\mathrm{ND}$ & - & $\mathrm{ND}$ & - & $\mathrm{ND}$ \\
Temperature supporting growth & & & & & & & \\
$\left({ }^{\circ} \mathrm{C}\right)$ & & & & & & & \\
0 & + & - & - & - & - & + & - \\
30 & + & + & + & + & + & - & + \\
40 & - & - & + & + & - & - & - \\
Salinity supporting growth & & & & & & & \\
$0 \cdot 5 \% \mathrm{NaCl}$ & + & - & - & + & - & - & - \\
$6 \%$ NaCl & + & + & + & + & + & + & - \\
$7 \%$ NaCl & - & - & + & - & + & + & - \\
Metabolism & A & $\mathrm{F}$ & $\mathrm{F}$ & $\mathrm{F}$ & $\mathrm{A}$ & $\mathrm{A}$ & $\mathrm{A}$ \\
Acid produced from carbohydrates & + & + & + & $\mathrm{ND}$ & - & - & + \\
Hydrolysis of: & & & & & & & \\
Agar & - & + & $\mathrm{ND}$ & - & - & - & $\mathrm{ND}$ \\
Aesculin & + & $\mathrm{ND}$ & + & $\mathrm{ND}$ & $\mathrm{ND}$ & - & $\mathrm{ND}$ \\
Gelatin & + & + & - & + & + & + & + \\
Starch & + & + & + & + & - & - & + \\
DNA & + & - & $\mathrm{ND}$ & $\mathrm{ND}$ & - & - & - \\
Urea & - & $\mathrm{ND}$ & - & + & - & - & - \\
Tween 20 & + & + & + & $\mathrm{ND}$ & - & $\mathrm{ND}$ & + \\
Tween 40 & + & + & - & + & + & $\mathrm{ND}$ & + \\
Tween 80 & + & - & - & $\mathrm{ND}$ & + & + & - \\
$\mathrm{H}_{2} \mathrm{~S}$ production from cysteine & + & - & $\mathrm{ND}$ & $\mathrm{ND}$ & + & - & + \\
Mean DNA G $+\mathrm{C}$ content $(\mathrm{mol} \%)$ & 34 & 34 & 38 & 37 & 36 \\
$\left(T_{\mathrm{m}}\right)$ & & & & & & & \\
& & & & & & & \\
\hline & & & & & & &
\end{tabular}

${ }^{\star} \mathrm{A}$, aerobic; F, fermentative.

\section{Description of Flaviramulus gen. nov.}

Flaviramulus (Fla.vi.ra' mu.lus. L. adj. flavus yellow; L. masc. nom. n. ramulus small branch, dim. of ramus branch or of things having a branching form; N.L. masc. n. Flaviramulus small yellow branch).

Cells are Gram-negative. Morphology varies with age of culture. Cells in exponential growth phase are rods, $0 \cdot 2-0 \cdot 3 \mu \mathrm{m}$ in diameter and $1-3 \mu \mathrm{m}$ in length. Cells in stationary phase are pleomorphic, $0 \cdot 2-0 \cdot 3 \mu \mathrm{m}$ in diameter but with lengths ranging from 1 to $30 \mu \mathrm{m}$. Branched and curled cells are also seen in stationary-phase cultures. As cultures age, cells degenerate into spheroplasts ranging from $0 \cdot 15$ to $1 \mu \mathrm{m}$ in diameter. Cells are motile, obligately aerobic heterotrophs. Cells contain yellow and orange carotenoids.
Flexirubin-type pigments are not found. Menaquinone- 6 is the major respiratory quinone. Phylogenetically, this is a member of the family Flavobacteriaceae, class Flavobacteria, phylum Bacteroidetes. The type and only species is Flaviramulus basaltis.

\section{Description of Flaviramulus basaltis sp. nov.}

Flaviramulus basaltis (ba.sal'tis. L. masc. gen. n. basaltis of basalt, pertaining to the source of isolation).

Has the following properties in addition to those given for the genus. Colonies grown on MA are shiny, dark yellow, circular, convex, with an entire margin. Cells are catalasepositive, oxidase-negative and alkaline phosphatase-positive. Growth occurs from $-2 \cdot 0$ to $34 \cdot 0{ }^{\circ} \mathrm{C}$, with optimum growth at $17 \cdot 5-22 \cdot 8{ }^{\circ} \mathrm{C}$. The salinity range for growth is 3-60 g sea salts $1^{-1}$, with an optimum of 24-60 $\mathrm{g} \mathrm{l}^{-1}$. Growth is supported at $\mathrm{pH} 6 \cdot 5-8 \cdot 6$, with optimum growth at $\mathrm{pH} 6 \cdot 5-8 \cdot 2$. Requires seawater, yeast extract or thiamine and amino acids for growth. Utilizes and produces acids from several sugars. Utilizes organic acids and amino acids. Does not utilize alcohols. Hydrolyses L-tyrosine, aesculin, carrageenan, gelatin, starch, DNA, urea, and Tweens 20, 40 and 80, but not agar, cellulose or chitin. Produces $\mathrm{H}_{2} \mathrm{~S}$ from cysteine. Mean DNA G $+\mathrm{C}$ content is $31 \cdot 4 \pm 0 \cdot 6 \mathrm{~mol} \%$ (SD) as determined by the thermal denaturation method. Branched fatty acids are predominant.

The type strain, $\mathrm{H} 35^{\mathrm{T}}\left(=\mathrm{CIP} 109091^{\mathrm{T}}=\mathrm{DSM} 18180^{\mathrm{T}}\right)$, was isolated from seafloor basalt offshore of Jan Mayen in the Norwegian/Greenland Sea at a depth of $1300 \mathrm{~m}$.

\section{Acknowledgements}

This work was supported by the Norwegian Research Council through the SUBMAR and BIODEEP project. Frida Lise Daae is thanked for the $\mathrm{G}+\mathrm{C}$ analyses. We thank Egil Severin Erichsen for assistance with the scanning electron microscopy, and Mathilde Skoie for help with etymology and Latin grammar. The crew of R/V Håkon Mosby and our fellow participants of the SUMBAR 2001 cruise are thanked for collecting and bringing the samples back in good condition.

\section{References}

Aasen, A. J. \& Ljaaen, J. S. (1966). Carotenoids of Flexibacteria IV. The carotenoids of two further pigment types. Acta Chem Scand 20, 2322-2324.

Bernardet, J. F., Segers, P., Vancanneyt, M., Berthe, F., Kersters, K. \& Vandamme, P. (1996). Cutting a gordian knot: emended classification and description of the genus Flavobacterium, emended description of the family Flavobacteriaceae, and proposal of Flavobacterium hydatis nom. nov. (basonym, Cytophaga aquatilis Strohl and Tait 1978). Int J Syst Bacteriol 46, 128-148.

Bernardet, J. F., Nakagawa, Y. \& Holmes, B. (2002). Proposed minimal standards for describing new taxa of the family Flavobacteriaceae and emended description of the family. Int J Syst Evol Microbiol 52, 1049-1070.

Bowman, J. P. (2005). The Marine Clade of the Flavobacteriaceae: the genera Aequorivita, Arenibacter, Cellulophaga, Croceibacter, Formosa, Gelidibacter, Gillisiia, Maribacter, Mesonia, Muricauda, Polaribacter, 
Psychroflexus, Psychroserpens, Robiginitaleav Salgenetibacter, Tenacibaculum, Ulvibacter, Vitellibacter and Zobellia. In The Prokaryotes: an Evolving Electronic Resource for the Microbiological Community. New York: Springer. http://link.springer-ny.com/link/ service/books/10125/

Bowman, J. P. \& Nichols, D. S. (2005). Novel members of the family Flavobacteriaceae from Antarctic maritime habitats including Subsaximicrobium wynnwilliamsii gen. nov., sp nov., Subsaximicrobium saxinquilinus sp. nov., Subsaxibacter broadyi gen. nov., sp. nov., Lacinutrix copepodicola gen. nov., sp. nov., and novel species of the genera Bizionia, Gelidibacter and Gillisia. Int J Syst Evol Microbiol 55, 1471-1486.

Campanella, J. J., Bitincka, L. \& Smalley, J. (2003). MatGAT: an application that generates similarity/identity matrices using protein or DNA sequences. BMC Bioinformatics 4 doi:10.1186/1471-2105-4-29.

Collins, C. H. (1995). Collins and Lynes Microbiological Methods, 7th edn. Oxford: Butterworth-Heinemann.

Felsenstein, J. (2004). PHYLIP - Phylogeny Inference Package, version 3.6. Distributed by the author. Department of Genome Sciences, University of Washington, Seattle, USA.

Garrity, G. M., Bell, J. A. \& Lilburn, T. (2005). The revised road map to the manual. In Bergey's Manual of Systematic Bacteriology, pp. 159-187. Edited by D. J. Brenner, N. R. Krieg \& J. T. Staley. East Lansing, MI: Springer.

Ivanova, E. P., Alexeeva, Y. V., Flavier, S., Wright, J. P., Zhukova, N. V., Gorshkova, N. M., Mikhailov, V. V., Nicolau, D. V. \& Christen, R. (2004). Formosa algae gen. nov., sp nov., a novel member of the family Flavobacteriaceae. Int J Syst Evol Microbiol 54, 705-711.

Jung, S. Y., Kang, S. J., Lee, M. H., Lee, S. Y., Oh, T. K. \& Yoon, J. H. (2005). Gaetbulibacter saemankumensis gen. nov., sp. nov., a novel member of the family Flavobacteriaceae isolated from a tidal flat sediment in Korea. Int J Syst Evol Microbiol 55, 1845-1849.

Kirchman, D. L. (2002). The ecology of Cytophaga-Flavobacteria in aquatic environments. FEMS Microbiol Ecol 39, 91-100.

Lapidus, I. R. \& Berg, H. C. (1982). Gliding motility of Cytophaga sp. strain-U67. J Bacteriol 151, 384-398.

Lewin, R. A. \& Lounsbery, D. M. (1969). Isolation, cultivation and characterization of flexibacteria. J Gen Microbiol 58, 145-170.
Mandel, M., Igambi, L., Bergenda, J., Dodson, M. L. \& Scheltge, E. (1970). Correlation of melting temperature and cesium chloride buoyant density of bacterial deoxyribonucleic acid. J Bacteriol 101, 333-338.

Marmur, J. (1963). A procedure for the isolation of deoxyribonucleic acid from microorganisms. Methods Enzymol 6, 726-728.

Nedashkovskaya, O. I., Kim, S. B., Han, S. K. \& 7 other authors (2004). Algibacter lectus gen. nov., sp nov., a novel member of the family Flavobacteriaceae isolated from green algae. Int J Syst Evol Microbiol 54, 1257-1261.

Nedashkovskaya, O. I., Kim, S. B., Han, S. K. \& 9 other authors (2005a). Winogradskyella thalassocola gen. nov., sp. nov., Winogradskyella epiphytica sp. nov. and Winogradskyella eximia sp. nov., marine bacteria of the family Flavobacteriaceae. Int J Syst Evol Microbiol 55, 49-55.

Nedashkovskaya, O. I., Kim, S. B., Lysenko, A. M., Frolova, G. M., Mikhailov, V. V. \& Bae, K. S. (2005b). Bizionia paragorgiae gen. nov., sp. nov., a novel member of the family Flavobacteriaceae isolated from the soft coral Paragorgia arborea. Int J Syst Evol Microbiol 55, 375-378.

Reichenbach, H. (1989). Family I. Cytophagaceae STANIER 1940, $630,{ }^{\mathrm{AL}}$ EMEND. In Bergey's Manual of Systematic Bacteriology, vol. 3, pp. 2015-2050. Edited by J. T. Staley. Baltimore: Williams \& Wilkins.

Slifkin, M. (2000). Tween 80 opacity test responses of various Candida species. J Clin Microbiol 38, 4626-4628.

Smibert, R. M. \& Krieg, N. R. (1994). Phenotypic characterization. In Methods for General and Molecular Bacteriology, pp. 607-654. Edited by P. Gerhardt, R. G. E. Murray, W. A. Wood \& N. R. Krieg. Washington, DC: American Society for Microbiology.

Stackebrandt, E. \& Goebel, B. M. (1994). Taxonomic note: a place for DNA-DNA reassociation and 16S rRNA sequence analysis in the present species definition in bacteriology. Int J Syst Bacteriol 44, 846-849.

Thompson, J. D., Gibson, T. J., Plewniak, F., Jeanmougin, F. \& Higgins, D. G. (1997). The CLUSTAL_X windows interface: flexible strategies for multiple sequence alignment aided by quality analysis tools. Nucleic Acids Res 25, 4876-4882. 